British Journal of Pharmaceutical Research

15(1): 1-10, 2017; Article no.BJPR.31614

ISSN: 2231-2919, NLM ID: 101631759

SCIENCEDOMAIN international

www.sciencedomain.org

\title{
Characterization and Microbiological Application of Ciprofloxacin Loaded in Natural Rubber Latex Membranes
}

\author{
B. C. Garms ${ }^{1}$, F. A. Borges ${ }^{1}$, R. E. Santos ${ }^{2}$, K. Nigoghossian ${ }^{1}$, \\ M. C. R. Miranda ${ }^{1}$, I. U. Miranda ${ }^{1}$, P. Daltro ${ }^{1}$, S. L. Scarpari ${ }^{1}$, R. J. Giagio ${ }^{1}$, \\ N. R. Barros ${ }^{1}$, K. M. Alarcon ${ }^{3}$, B. C. Drago ${ }^{4}$, J. L. P. Gemeinder ${ }^{2}$, \\ B. H. Oliveira ${ }^{2}$, V. M. G. Nascimento ${ }^{2}$, A. V. Loffredo ${ }^{2}$ and R. D. Herculano ${ }^{3}$ \\ ${ }^{1}$ Instituto de Química, UNESP, Rua Francisco Degni 55, 14800-900 Araraquara, Brazil. \\ ${ }^{2}$ Faculdade de Ciências e Letras, UNESP, Av. Dom Antônio 2100, 19806-900, Assis, Brazil. \\ ${ }^{3}$ Faculdade de Ciências Farmacêuticas, UNESP, Rodovia Araraquara-Jaú Km 01, 14801-902, \\ Araraquara, Brazil. \\ ${ }^{4}$ Faculdade de Ciências, UNESP, Av. Luiz Edmundo Carrijo Coube 14-01, 17033-360, Bauru, Brazil.
}

Authors' contributions

This work was carried out in collaboration between all authors. Authors RDH and BCG designed the study. Authors FAB and NRB performed the statistical analysis, wrote the protocol and wrote the first draft of the manuscript. Authors RES, KN, MCRM, IUM, PD, JLPG, BHO, VMGN and AVL managed the analyses of the study and the literature searches. All authors read and approved the final manuscript.

Article Information

DOI: 10.9734/BJPR/2017/31614 Editor(s):

(1) Othman Ghribi, Department of Pharmacology, Physiology \& Therapeutics, University of North Dakota, USA. Reviewers: (1) Akindele Peter Oluwayinka, Federal University of Technology, Akure, Nigeria. (2) R. K. Upadhyay, D D U Gorakhpur University, U.P., India. Complete Peer review History: http://www.sciencedomain.org/review-history/18126

Original Research Article

Received $16^{\text {th }}$ January 2017 Accepted $27^{\text {th }}$ February 2017 Published $9^{\text {th }}$ March 2017

\section{ABSTRACT}

Natural rubber latex (NRL) from Hevea brasiliensis presents interesting characteristics in biomedical research due to its ability to stimulate angiogenesis, cellular adhesion and formation of extracellular matrix. A broad spectrum antibacterial agent used in skin infection is Ciprofloxacin hydrochloride (CIP). It is a fluoroquinolone employed to treat different bacterial infections caused by gram-positive and gram-negative microorganism. The aim of the present study is to promove 
the CIP incorporation on the natural material due to develop a biomaterial which could accelerate tissue repair and control wounds infection. The biomaterial characterization was made through several technics. The compound presence on the membrane was observed by Scanning Electron Microscopy technique, which shown crystals merged on the material surface. Through X-Ray Powder Diffraction technic was possible to notice the absence of crystallinity (amorphous structure) in the drug-loaded NRL membrane indicating that the drug is molecularly dispersed within the NRL. Besides that, there are no molecular interaction between drug and NRL showed by Fourier Transform Infrared Spectroscopy neither Raman spectroscopy. Additionally, there were no significant changes in the NRL pyrolysis profile when the drug was added, indicating weak interaction between both compounds, as presented by Derivative Thermogravimetric Analysis assay. Comparing the mechanical properties, both samples (with and without CIP) had a similar behavior. Thus, is possible to presume the material preserved enough elasticity to medical application. Furthermore, antimicrobial assay proved that CIP activity was preserved after its incorporation to the NRL. It allows us to conclude that the material has potential application in infected wound treatment.

Keywords: Natural rubber latex; biopolymers; drug delivery system; ciprofloxacin; biomaterials; membranes; antibacterial activity.

\section{INTRODUCTION}

\subsection{Drug Delivery Systems}

Pharmaceutical industry is constantly updating its technology due to provide a drug with high efficiency and more attractive properties. Among the characteristics which have been seeking are the decrease of side effect, a faster drug response and high specification. Conventional drug formulations are mostly made in higher concentration and with a short half-life, these shortcomings lead the patient to consume more drug than is necessary to cause the desired effect $[1,2]$. These can results in side effects increase, allergies, and antibiotic resistance.

Drug Delivery System (DDS) shows up as an alternative to overcome these issues. This method allows interaction between drug and the target organ/tissue in a more specific way. DDS consists on delivering the drug in a lower concentration, a controlled form along a previously established period of time [3,4]. It brings advantages as the reduction in the frequency of the drug dosages taken by the patient, more uniform drug effect, reduction of drug side-effects, and reduced fluctuation in circulating drug levels.

Biomaterials have been seen as an interesting tool for DDS. A widely number of materials has been explored to this application. Different sources has been used, such as metallic, ceramic and polymerics $[4,5]$.

\subsection{Natural Rubber Latex}

A polymeric material with interesting characteristics in DDS is the natural rubber latex (NRL). It consists in cis-1,4-polyisoprene, extracted from Hevea brasiliensis, widely employed as raw material. In the industry, the material is found in the manufacturing of gloves, condoms, balloons, and other medical and dental devices $[1,3,6]$. The mechanical properties are its strengths; its of easy manipulation, low cost product and presents high mechanical resistance.

The material has also increased biomedical interest due to its angiogenic properties [7-10]. Studies have presented NRL capacity to stimulate vascularization and ability to induce tissue regeneration $[8,11]$. Since then, the NRL has been used for various therapeutic purposes such as, palate reconstruction in dogs, stomach regeneration in rabbits and the treatment of ulcers of different etiologies [6-11].

\subsection{Ciprofloxacin}

Ciprofloxacin hydrochloride (CIP), $\mathrm{C}_{17} \mathrm{H}_{18} \mathrm{FN}_{3} \mathrm{O}_{3}$ (Fig. 1), is a broad spectrum fluoroquinolone antibacterial agent. Fluoroquinolones inhibit DNA gyrase, which is an enzyme that plays a key role in metabolism and bacterial reproduction. There are two quinones generation, and the secondgeneration is the group which CIP is on $[12,13]$. Antibiotics from this generation have shown activity against Gram-negative and Grampositive bacteria and also against certain 
pathogens [14]. It makes CIP an antibiotic with potential application on wound infections.<smiles>O=C(O)c1cn(C2CC2)c2cc(N3CCNCC3)c(F)cc2c1=O</smiles>

Fig. 1. Structural formula of ciprofloxacin hydrochloride

The present study aims to develop a membrane of NRL loaded with CIP to accelerate tissue repair and control wounds infection. Furthermore, it is focus on the characterization of the new biomaterial as its structure, morphology and resistance and also assesses its microbiological activity.

\section{MATERIALS AND METHODS}

\subsection{Membranes}

\subsubsection{Natural rubber latex}

Due to prepare the NRL membranes, it was used the commercial natural latex (BDF Rubber Latex Co. Ltd., Guarantã, Brazil). The material consists in about $60 \%$ dry rubber content (DRC), $4-5 \%$ weight of non-rubber constituents such as protein, lipids, carbohydrates, and sugar, and $35 \%$ of water [15]. After it been extracted, ammonia was used to maintain the latex liquid. A centrifugation processes was performed at 8,000 g $[3,7]$ to reduce protein contents related with allergies.

\subsubsection{Ciprofloxacin}

CIP powder obtained from gel capsules (Callithea Pharmaceutics Ltd., Brazil). The encapsulated drug is excipient free. Only the powder was used to perform the experiment. CIP was solubilized in water to facilitate the membranes preparation and a concentration of $10 \mathrm{mg} \cdot \mathrm{mL}^{-1}$ was adopted.

\subsubsection{Membrane production}

NRL loaded with CIP (10 mg. $\mathrm{mL}^{-1}$ ) membranes were prepared by casting method [1]. The membranes presented $30 \mathrm{mg}$ of CIP and $1: 1$ of CIP solution to natural rubber latex solution.
Then, the resulting solution was poured into Petri dishes and maintained at room temperature $\left(25^{\circ} \mathrm{C}\right)$ for $48 \mathrm{~h}$ until complete polymerization. The CIP in the solution was analyzed by measuring the UV-VIS spectra (Bel Engineering SF200 ADV spectrophotometer), as the drug has its maximum absorption at $275 \mathrm{~nm}$.

\subsection{Characterization}

\subsubsection{Scanning electron microscopy (SEM)}

To observe the NRL surface morphology, SEM (model Zeiss ${ }^{\circledR}$ EVO 50) was performed at an accelerating voltage of $20 \mathrm{KV}$ and a take off angle of $35^{\circ}$.

\subsubsection{X-ray powder diffraction (XRD)}

The materials crystal phase was identified by XRD (Siemens D5005) using X-ray diffractometer and a graphite crystal as monochromator to select $\mathrm{Cu} \mathrm{Ka} 1$ radiation $(1.5406 \AA)$, in a step of $0.02^{\circ} \mathrm{s}^{-1}$.

\subsubsection{Fourier transform infrared spectroscopy (FT-IR)}

The FT-IR spectra of CIP powder, NRL membrane and NRL + CIP membrane were obtained to prove the chemical integrity of the drug in the polymer. The samples were measured directly by Attenuated Total Reflection (ATR) method, which is an excellent method for obtaining infrared information for the powder sample surface. The membranes were characterized using a TENSOR T 27 (Bruker, Germany) $\left(4000-500 \mathrm{~cm}^{-1}\right)$ with a resolution of 4 $\mathrm{cm}^{-1}$ with 16 scans.

\subsubsection{Raman spectroscopy}

The FT-Raman spectrum has been recorded using $632.81 \mathrm{~nm}$ line of $\mathrm{He}-\mathrm{Ne}$ laser as excitation wavelength in the region $50-3500 \mathrm{~cm}^{-1}$ on a HORIBA JOBIN-YVON model LabRAM HR 800 spectrometer equipped with a CCD camera model DU420A-OE-325. It was analyzed samples of CIP (powder), NRL and NRL + CIP.

\subsubsection{Thermogravimetric and derivative thermogravimetric analysis}

Thermogravimetric (TG) and derivative thermogravimetric (DTG) curves were obtained from NRL membrane, NRL + CIP membrane and CIP powder. These samples were studied by TG 
using SDT Q600 V8.3 Build 101 thermal analyzer instrument, ranging from 25 to $1000^{\circ} \mathrm{C}$ at a heating rate of $10^{\circ} \mathrm{C} \mathrm{min}{ }^{-1}$, using alumina pans under dynamic nitrogen atmosphere $(100 \mathrm{~mL}$ $\min ^{-1}$ ).

\subsubsection{Mechanical assay}

Tensile tests were carried out in a EMIC DL2000 fitted with $10 \mathrm{kgf}$ load cell at a rate of $500 \mathrm{~mm} / \mathrm{min}$ (according to ASTM D412). To perform the assay, NRL samples $(44 \times 15 \times$ $1.0 \mathrm{~mm}$, length $\times$ width $\times$ thickness), with and without CIP, were prepared. The membranes were submitted to elongation to failure. The tensile tests by pulling apart the specimen were performed at room temperature.

\subsection{Antibacterial Activity}

\subsubsection{Bacteria strain}

In order to perform the antibacterial assay, Burkholderia lata (LBBIO-BL02) was isolated from a fungal culture contamination and identified by morphological and molecular methods (16S RNA) at Fundação André Tosello (FAT), Campinas - SP - Brazil [16].

\subsubsection{Broth dilution method}

Flasks in triplicate containing $8 \mathrm{~mL}$ of LB (Luria Bertani) broth were incubated at $28^{\circ} \mathrm{C}$ for $48 \mathrm{~h}$.
The control 1 (C1) was LB broth without inoculation, control 2 (C2) was LB broth inoculated with B. lata, control 3 (C3) was LB broth inoculated with bacteria and the NRL membrane. The Experiment (E1) had in its composition bacteria and NRL incorporate with CIP (Table 1).

\section{RESULTS AND DISCUSSION}

\subsection{Scanning Electron Microscopy Analysis}

SEM is a very versatile technique, which is mostly used to analyses microstructure of solids. The assay allows us to measure pore size and distribution, and the membranes composition, with and without CIP [17-19].

Fig. 2a brings CIP SEM image, where is possible to notice crystals of different sizes and shapes, closely united. The crystals formed a homogeneously matted surface of CIP. In Fig. $2 b$ we can notice the presence of CIP crystals incorporated into the membrane. NRL when is not loaded with the drug, has a uniform surface morphology as showed in Fig. 2c, typical of amorphous material. It is possible to observe that the surface has been modified after CIP incorporation. As the drug merges with the NRL it forms a complete homogeneous coating of the drug crystals $[1,20]$.

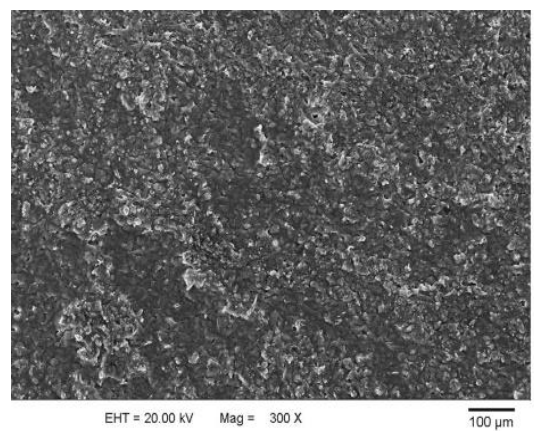

(A)

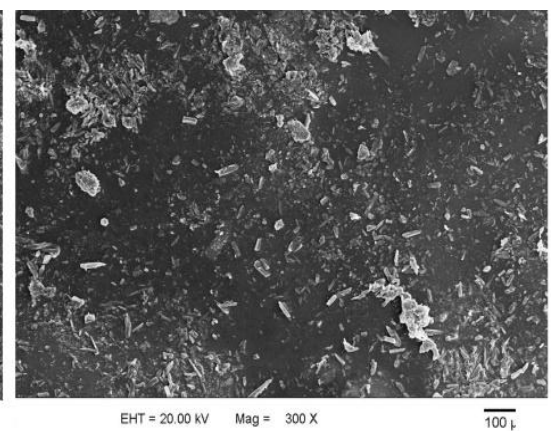

(B)

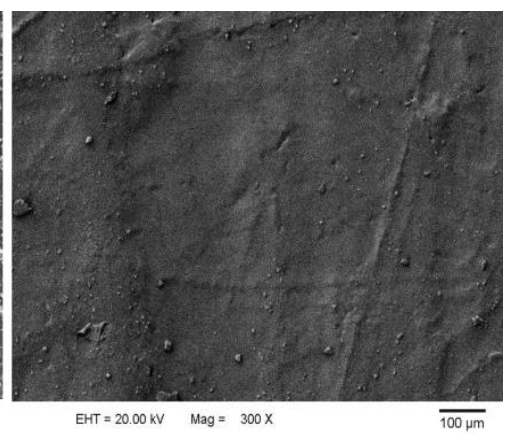

(C)

Fig. 2. 300x SEM morphology at an accelerating voltage of $20.000 \mathrm{kv}$ : a) CIP crystals, b-) NRL + CIP and c-) NRL membrane. Note the CIP presence on the NRL matrix (b)

Table 1. The cell growth inhibition assay

\begin{tabular}{lllll}
\hline & C1 & C2 & C3 & E1 \\
\hline Test tubes & LB broth & LB broth & LB broth & LB broth \\
composition & & Bacterium & Bacterium & Bacterium \\
& & NRL & & NRL + CIP \\
\hline
\end{tabular}




\subsection{X-ray Diffraction Analysis}

The main application of XRD refers to the identification of crystalline compounds, either organic or inorganic. This technique was used for structural characterization of NRL, NRL + CIP and CIP. Fig. 3 shows the diffractograms of NRL incorporated with the drug (NRL+CIP) and its components separately. The XRD patterns obtained for the NRL without CIP exhibits the amorphous structure of the material, as expected [21]. All peaks are related in accordance with the reference pattern obtained from the literature $[22,23]$. Due to CIP cristallinity, XRD has different pattern than an amorphous material, forming many peaks on the chart, as we can see in Fig. 3. After CIP had been incorporated into the membrane, peaks intensity have decreased. The absence of crystallinity in the drug-loaded NRL membrane indicates that the drug is molecularly dispersed within the NRL [24]. Studies have reported a reduction in peak intensity for drugs merged in polymers materials. Is is explained by the drug concentration found on the surface not being enough to provide peaks [25].

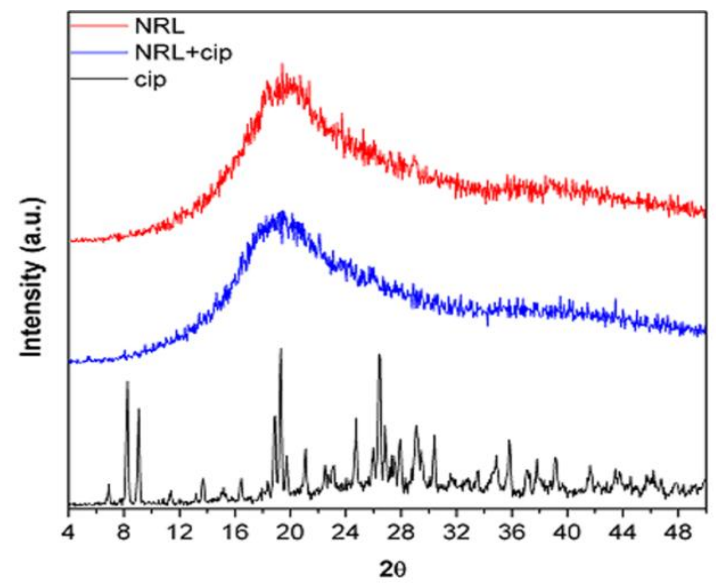

Fig. 3. X-ray diffraction patterns of NRL+CIP (blue line), NRL (red line) and CIP powder (black line)

\subsection{Fourier Transform Infrared Spectroscopy}

FT-IR spectrum of NRL is presented in Fig. 4. The cis-1,4-polyisoprene absorption band of strong amplitude corresponding to $=\mathrm{CH}$ out of plane bending is observed at $835 \mathrm{~cm}^{-1}$. However, the trans isomer has no absorption at this wavelength [24,26,27]. The absorptions bands at $1375 \mathrm{~cm}^{-1}$ and $1432 \mathrm{~cm}^{-1}$ are characteristics of $\mathrm{CH}_{2}$ and $\mathrm{CH}_{3}$ asymmetric stretching, respectively. The $\mathrm{CH}_{2}$ symmetric stretching vibrations are observed at the region $2852 \mathrm{~cm}^{-1}$ -
$2925 \mathrm{~cm}^{-1}$. The $\mathrm{CH}_{3}$ asymmetric stretching in FTIR of NRL is observed at $2961 \mathrm{~cm}^{-1}$ [28]. In addition, Fig. 4 also shows a broad peak at approximately $3200-3500 \mathrm{~cm}^{-1}$. This absorption band might be related to the presence of a hydroxyl group, which appears to be generated after the hydrolytic ring opening of epoxy groups formed during the casting of NRL membranes.

In the FT-IR spectrum of the CIP (Fig. 4) the absorption band observed at $1708 \mathrm{~cm}^{-1}$ corresponds to carbonyl group. Moreover, one prominent characteristic peak, between 3500 and $3450 \mathrm{~cm}^{-1}$, was assigned to $\mathrm{OH}$ stretching vibration (intermolecular hydrogen bonding). The bands at 1750 to $1700 \mathrm{~cm}^{-1}$ represent carbonyl $\mathrm{C}=\mathrm{O}$ stretching, i.e., $\mathrm{C}=\mathrm{O}$ while the peak at 1650 to $1600 \mathrm{~cm}^{-1}$ are assigned to quinolones. The bands at the 1450 to $1400 \mathrm{~cm}^{-1}$ are attributed to UC-O and the ones at 1300 to $1250 \mathrm{~cm}^{-1}$ suggest bending vibration of $\mathrm{O}-\mathrm{H}$ group which indicated the presence of carboxylic acid [1,29-31].

In the FT-IR spectrum of the polymer and drug (Fig. 4) was not altered after immobilization in the latex membrane. Due to the low drug concentration, some of the CIP peaks are missing in the NRL + CIP spectrum. However, the FTIR spectrum of NRL + CIP showed most of the characteristic bands of CIP and NRL, indicating that the stability of the drug after its incorporation were maintained.

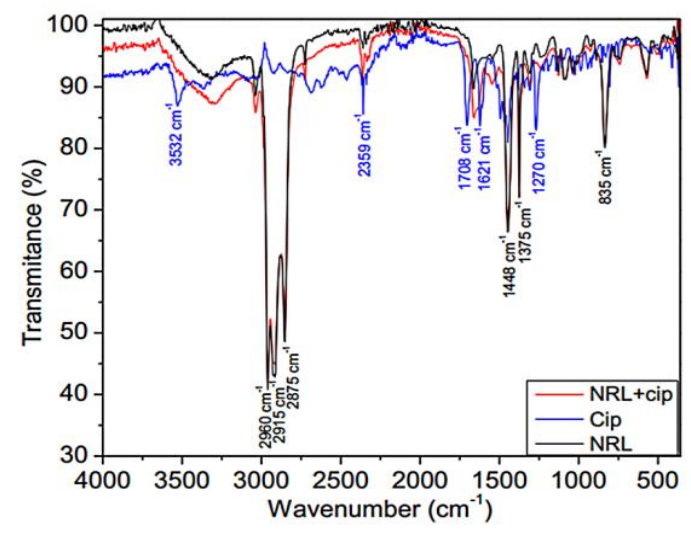

Fig. 4. FT-IR spectra of NRL membrane incorporated with CIP; NRL; and CIP powder

\subsection{Raman Spectroscopy}

Raman spectroscopy was performed due to identify the molecular vibrations of CIP powder, $N R L$ and NRL+CIP membranes. According to Skoulika et al. [32], bands of CIP can be observed at 1624, 1575, 1384, $752 \mathrm{~cm}^{-1}$. In addition, bands of NRL membrane were identified at 1001, 1452, 1666 and $2914 \mathrm{~cm}^{-1}$, in 
agreement with Agostini et al. [33] and Job et al. [34]. Finally, we observed bands of CIP loaded $\mathrm{NRL}$ membrane at 1001, 1452, $1666 \mathrm{~cm}^{-1}$ (Fig. 5).

Raman bands of CIP spectrum (Fig. 5) at 1624, 1575 , and $1378 \mathrm{~cm}^{-1}$ are attributed to the $\mathrm{n}(\mathrm{COOH}), \mathrm{n}\left(\mathrm{C}_{5} \mathrm{O}\right)$, and also to antisymmetric and symmetric $\mathrm{n}(\mathrm{O}-\mathrm{C}-\mathrm{O})$ vibrations, respectively. Lee et al. [35] assigned the band around 1624 $\mathrm{cm}^{-1}$ to the $\mathrm{C}_{5} \mathrm{O}$ stretch of different modes belonging to in-phase and out-of-phase vibrations. Bands around $752 \mathrm{~cm}^{-1}$ are characteristic of the substituted benzene ring deformation modes.

The $1024 \mathrm{~cm}^{-1}$ band is characteristic of the $\mathrm{n}(\mathrm{CC})$ skeletal conformation stretching modes, while the $752 \mathrm{~cm}^{-1}$ band is attributed to methylene rocking modes $[32,35,36]$. The band at $805 \mathrm{~cm}^{-1}$ is attributed to the $\mathrm{CH}$ out-of-plane bending mode [36].

Raman bands of the NRL membrane spectrum at 1001,1666 , and $2914 \mathrm{~cm}^{-1}$ are attributed to $=\mathrm{C}$ $\mathrm{H}$, cis $-(\mathrm{C}=\mathrm{C})$ and stretching $\mathrm{CH}$, respectively [37].

\subsection{Thermogravimetric and Derivative Thermogravimetric Analysis}

The TG analysis showed that the NRL had higher mass loss than the others samples, due to the absence of the drug on the polymer. Similar effects have been reported in thermal analysis of NRL membrane without additives (carbon black, sulfur, antioxidant) added the vulcanization process [38].

The TG of NRL + CIP was decomposed in a single step. Thus, NRL had higher pyrolysis $\left(357^{\circ} \mathrm{C}\right)$ among all samples, while NRL+CIP and CIP powder were about $380^{\circ} \mathrm{C}$ and $358^{\circ} \mathrm{C}$, respectively. Comparing to the plain NRL the onset decomposition temperature decreased with the addition of CIP into the NRL. This may be occurred due to the crystallinity of the drug molecules [40]. Similar behavior of onset decomposition temperature was reported by Unnithan et al. [39], in this study they added dextran in the polyurethane-dextran blended nanofibers and polyurethane-dextranciprofloxacin loaded nanofibers. The data obtained in this work demonstrated a significant difference in the thermal stability between the samples, as shown in Fig. 6.

The DTG curves of thermal decomposition of NRL, NRL loaded CIP and CIP powder, at heating rate $10^{\circ} \mathrm{C} \mathrm{min}^{-1}$ under nitrogen atmosphere are shown in Fig. 7. DTG profile $\mathrm{NRL}+\mathrm{CIP}$ membrane indicated that the number of degradation stages was modified by incorporation of CIP into the NRL matrix evidencing drug-polymer interactions during thermal decomposition. Macocinschi et al. [40]

a)

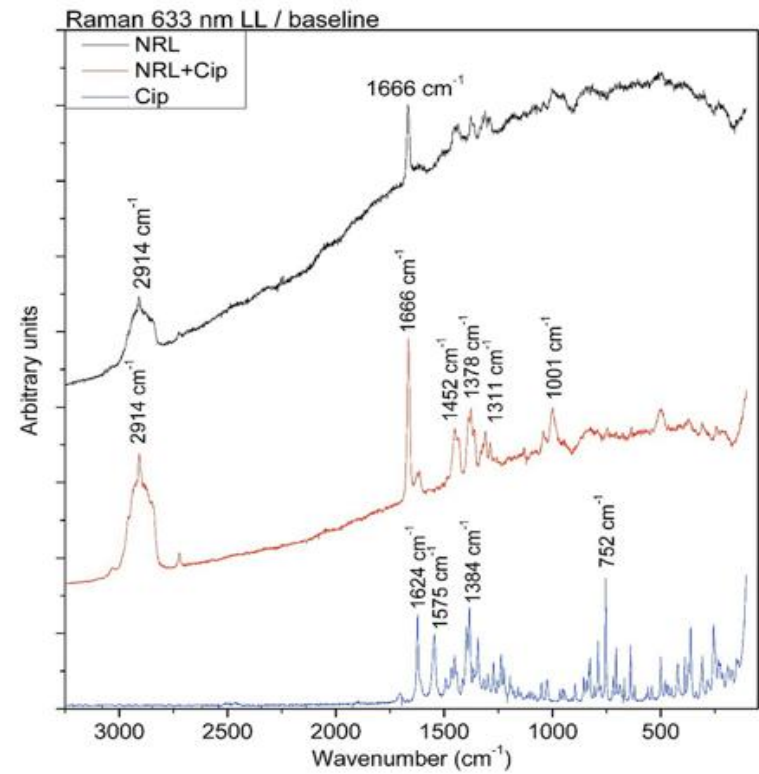

b)

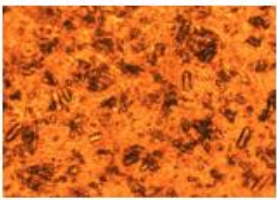

c)

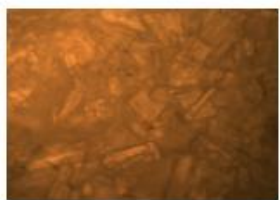

Fig. 5. Raman spectra (a). The area where Raman spectra were collected showed in a microscopy image: NRL + CIP membrane (b) and CIP crystals powder (c) 
reported similar behavior of DTG, once that the main degradation stage was around $400^{\circ} \mathrm{C}$ with mass loss between $69.8 \%$ and $79.0 \%$. Its higher temperature is similar with the temperature in present study $\left(376.54^{\circ} \mathrm{C}\right)$, although mass loss $(52.95 \%)$ is lower. It occurs because a different compound (CIP) was associated with the polymer, which was composed of degradation step in the range of $202.00-530.74^{\circ} \mathrm{C}$. There were no significant changes in the NRL pyrolysis profile when the drug was added, indicating weak interaction between both compounds.

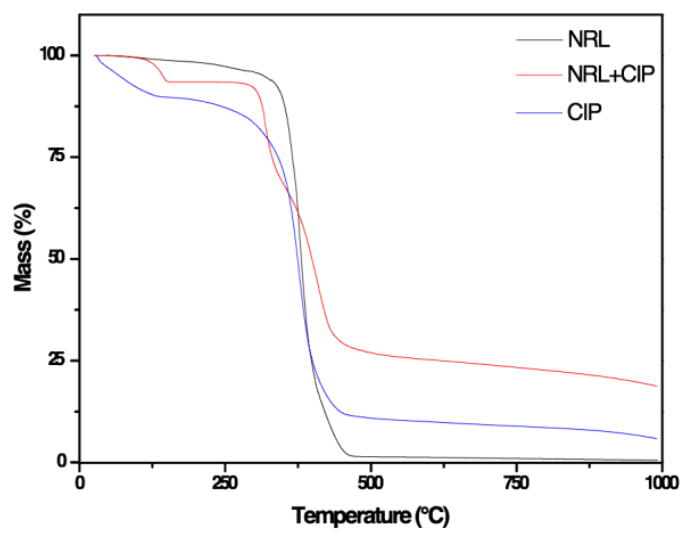

Fig. 6. TG curves for NRL, NRL + CIP and CIP

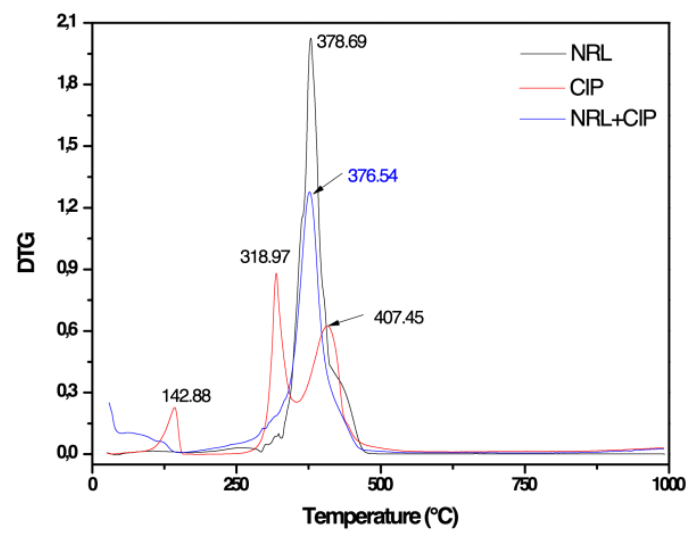

Fig. 7. DTG curves for NRL; NRL + CIP; and CIP (red line)

\subsection{Tensile Stress-strength Strain}

The CIP addition to the latex membrane had influence on the mechanical behavior of NRL (Fig. 8). We observed that the addition of CIP increased 1.03 times the elongation at break and had the tensile strength reduced in 1.07 times. The elongation at break, tensile strength and Young's Modulus of NRL membrane were $853.614 \%, \quad 1.555 \mathrm{MPa}$ and $1.203 \mathrm{MPa}$, respectively. Furthermore, the elongation at break, tensile strength and Young's Modulus of CIP loaded NRL membrane were $876.001 \%$, $1.456 \mathrm{MPa}$ and $1.181 \mathrm{MPa}$, respectively. We found that the mechanical properties of the drugloaded polymer is similar to NRL membrane $[20,39,40,41]$.

\subsection{Antibacterial Activity}

\subsubsection{Broth dilution method}

In the present assay, the turbidity of the culture medium is related to cell growth. It was observed that NRL by itself has no bactericidal effect (C2), once it had no inhibition action under the bacteria growth. However, when NRL membrane is loaded with CIP (E1), we observed the complete bacteria inhibition by the material (Fig. 9).

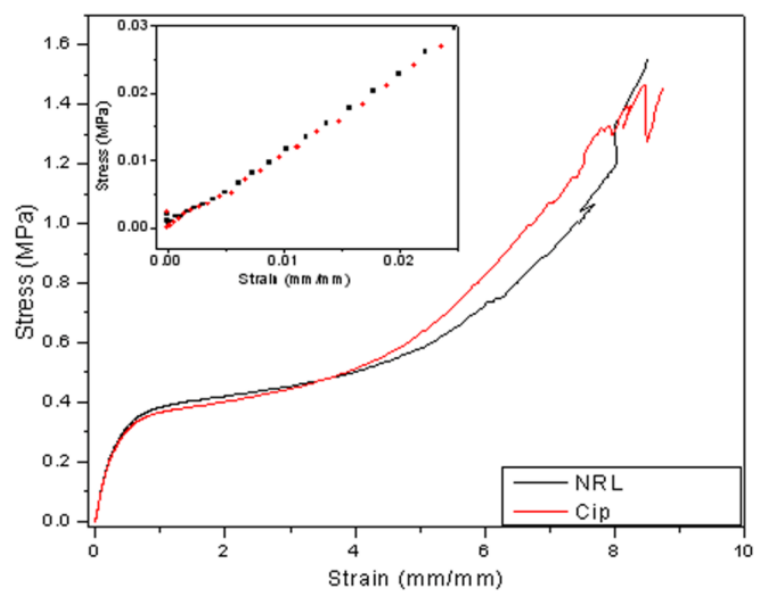

Fig. 8. Tensile stress-strength strain curves of NRL and NRL + CIP

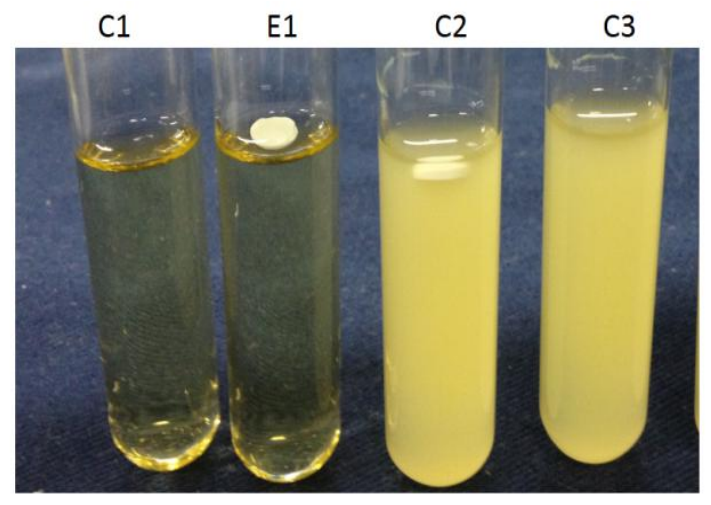

Fig. 9. Photography shows the inhibition of $B$. lata by NRL + CIP membrane (E1); C1: LB broth; C2: NRL (without CIP) in contact with LB broth inoculated with B. lata; C3: LB broth inoculated with $B$. lata 


\section{CONCLUSION}

A new biomembrane made by $\mathrm{NRL}+\mathrm{CIP}$ has been characterized through different methods. The CIP presence on the membrane surface was showed by SEM, which allowed us to see crystals of the drug merged on the rubber membrane. XRD technique presented the absence of crystallinity in the drug-loaded NRL membrane indicating that the drug is molecularly dispersed within the NRL. FT-IR and Raman spectroscopy showed that there is no molecularlevel interaction between drug and NRL. The TG assay demonstrated a significant difference between the samples in the thermal stability, but no significant changes in the NRL pyrolysis profile was observed. It indicates a weak interaction between both compounds, as presented by DTG assay. Mechanical properties of the NRL+CIP are similar to NRL. Although the addition of CIP increased 1.03 times the elongation at break and 1.07 times reduced the tensile strength, it still has enough elasticity to be used as a biomaterial for medical application. Moreover, antimicrobial assay showed that $\mathrm{NRL}+\mathrm{CIP}$ membrane presents antibacterial activity to Burkholderia cepacia complex (Bcc), where the control LB grown broth (C1) and the $\mathrm{NRL}+\mathrm{CIP}(\mathrm{E} 1)$ are quite the similar in terms of cell concentration.

\section{CONSENT}

It is not applicable.

\section{ETHICAL APPROVAL}

It is not applicable.

\section{ACKNOWLEDGEMENT}

The authors acknowledge Fapesp (Processes 2014/17526-8 and 2011/17411-8) for the financial support.

\section{COMPETING INTERESTS}

Authors have declared that no competing interests exist.

\section{REFERENCES}

1. Herculano RD, Silva CP, Ereno C, Catanzaro-Guimarães AS, Kinhoshita A, Graeff CFO. Natural rubber latex used as drug delivery system in guided bone regeneration. Materials Research. 2009; 12(2):253-256.

2. Sona SC, Hetal KP, Punit BP, Pragna KS. Chronomodulated drug delivery system of urapidil for the treatment of hypertension. International Journal of Pharmaceutical Investigation. 2015;5(2):107-113.

3. Herculano RD, Tzu LC, Silva CP, Brunello CA, Queiroz AAA, Kinoshita A, Graeff CFO. Nitric oxide release using natural ruber latex as matrix. Materials Research. 2011;14(3):355-359.

4. Swamy BY, Yun YS. In vitro release of metformin from iron (III) cross-linked alginate- carboxymethyl cellulose hydrogel beads. International Journal of Biological Macromolecules. 2015;77:114-119.

5. Martins EAN, Invernizzi MS, Campos MGN, Teodoro PA, Contieri MB, Silva LCLC. Emprego de membrana de quitosana em feridas cutâneas induzidas experimentalmente em equinos. Ciência Rural. 2013;43(10):1824-1830.

6. Talieri IC, Laus JL, Coutinho-Neto J, Luvizotto MCR, Paula MC. Natural latex graft in lamellar and penetrating sclerectomies in rabbits. Ciência Rural. 2009;39(6):1815-1822.

7. Mrué F, Coutinho NJ, Ceneviva R, Lachat JJ, Thomazini JA, Tambelini H. Evaluation of the biocompatibility of a new biomembrane. Materials Research. 2004;7(2):277-283.

8. Silva EB, Maniscalco CL. Palatoplastia com biomembrana natural de látex com polilisina $0,1 \%$ em cães com defeito palatino experimentalmente induzido. Semina: Ciências Agrárias. 2013;34(2): 785-92.

9. Ferreira ARS, Machado MRF, Melo VS, Martins LL, Leal LM, Sartori LCA. Avaliação macroscópica e microscópica de implante de Biomembrana em estômago de coelhos (Oryctolagus cuniculus). Arquivo Brasileiro de Medicina Veterinária e Zootecnia. 2014;66(1):177-184.

10. Ganga MVM, Coutinho-Netto J, Colli BO, Junior WM, Catalão $\mathrm{CH}$, Santana RT, Oltramari MRP, Carraro KT, Lachat JJ, Lopes LS. Sciatic nerve regeneration in rats by a nerve conduit engineering with a membrane derived from natural latex. Acta Cirúrgica Brasileira. 2012;27(12):885-91.

11. Kanokwiroon K, Teanpaisan R, Wititsuwannakul D, Hooper AB, Wititsuwannakul R. Antimicrobial activity of a protein purified from the latex of Hevea 
brasiliensis on oral microorganisms. Mycoses. 2008;51(4):301-307.

12. Nisar $M$, Khan SA, Qayum $M$, Jhan $A$, Farooq U, Jaafar HZE, Zia-UI-Haq M, Ali R. Robust synthesis of ciprofloxacincapped metallic nanoparticles and their urease inhibitory assay. Molecules. 2016;21(411):1-12.

13. Khan I, Ali S, Hameed S, Rama $\mathrm{NH}$, Hussain MT, Wadood A, Uddin R, Ul-Haq Z, Khan A, Ali S, et al. Synthesis, antioxidant activities and urease inhibition of some new 1,2,4-triazole and 1,3,4thiadizole derivatives. European Journal of Medical Chemistry. 2010;45:5200-5207.

14. Postma DF, Werkhoven CHV, Elden LJRV, Thijsen SFT, Hoepelman AIM, Kluytmans JAJW, Boersma WG, Compaijen CJ, Wall EVD, Prins JM, Oosterheert JJ, Bonten MJM. Antibiotic treatment strategies for community-acquired pneumonia in adults. The New England Journal of Medicine. 2015;372:1312-1323.

15. Othman AB, Hepbur C, Hasma $H$. Influence of non-rubber constituents on elastic properties of natural rubber vulcanizates. Plastics and Rubber Processing and Applications. 1993;19: 185-94

16. Oliveira $\mathrm{BH}$, Santos RE, Loiola LEA, Nascimento VMG. Overproduction and properties of lipase by a wild strain of Burkholderia lata LBBIO-BL02 using chicken fat. Annals of Microbiology. 2015;65(2):865-877.

17. Sonia TA, Sharma CP. Chitosan and its derivatives for drug delivery perspective. Advances in Polymer Science. 2011; 243(1):23-54

18. Herculano RD, Catanzaro-Guimarães SA, Belmonte GC, Duarte MAH, Oliveira-Jr ON, Kinoshita A, Graeff CFO. Metronidazole release using natural rubber latex as matrix. Materials Research. 2010;13:57-61.

19. Wang LY, Ma GH, Su ZG. Preparation of uniform sized chitosan microspheres by membrane emulsification technique and application as a carrier of protein drug. Journal of Controlled Release. 2005; 106(1-2):62-75.

20. Murbach HD, Ogawa GJ, Borges FA, Cinman JLF, Drago BC, Miranda MCR, Lopes R, Silva RG, Barros NR, Herculano RD. Ciprofloxacin release using natural rubber latex membranes as carrier.
International Journal of Biomaterials. 2014;2014:1-7.

21. Herculano RD, de Queiroz AAA, Kinoshita A, Oliveira Jr ON, Graeff CFO. On the release of metronidazole from natural rubber latex membranes. Materials Science and Engineering C. 2011;31:272275.

22. Turel I, Bukovec P, Quirós M. Crystal structure of ciprofloxacin hexahydrate and its characterization. International Journal of Pharmaceutics. 1997;152:59-65.

23. Sahoo S, Chakraborti CK, Naik S, Mishra SC, Nanda UN. Structural analysis of ciprofloxacin-carbopol polymeric composites by X-Ray diffraction and fourier transform infra-red spectroscopy. Tropical Journal of Pharmaceutical Research. 2011;10(3):273-280.

24. Angulo-Sanchez JL, Cabollero-Mato $P$. Long chain branching in natural Hevea rubber - determination by gel permeation chromatography. Rubber Chemistry and Technology. 1981;54:34-43.

25. Barros NR, Miranda MCR, Borges FA, Mendonça RJ, Cilli EM, Herculano RD. Oxytocin sustained release using natural rubber latex membranes. International Journal of Peptide Research and Therapeutics; 2016.

26. Nallasamy $P$, Mohan S. Vibrational spectra of cis-1,4-polyisoprene. Arabian Journal for Science and Engineering. 2004;28(1):1726.

27. Tarachiwin L, Sakdapipanich J, Ute K, Kitayama T, Tanaka Y. Structural characterization of a-terminal group of natural rubber: 2 . decomposition of branchpoints by phospholipase and chemical treatments. Biomacromolecules. 2005;6: 1858-1863.

28. Tata SJ. Distribution of proteins between the fractions of Hevea latex separated by ultracentrifugation. Journal of the Rubber Research Institute of Malaysia. 1980;28:77-83.

29. De Mello VA, Ricci-Júnior E. Encapsulation of naproxen in nanostructured system: structural characterization and in vitro release studies. Quimica Nova. $2001 ; 34(6): 933-939$.

30. Agostini DLS, Constantino CJL, Job AE. Thermal degradation of both latex and latex cast films forming membranes. Journal of Thermal Analysis and Calorimetry. 2008;91:703-707. 
31. Ferreira M, Mendonça RJ, Coutinho-Netto $\mathrm{J}$ and Mulato M. Angiogenic properties of natural rubber latex biomembranes and the serum fraction of Hevea brasiliensis. Brazilian Journal of Physics. 2009;39:564569

32. Skoulika SG, Georgiou SA. Rapid quantitative determination of ciprofloxacin in pharmaceuticals by use of solid-state FT-Raman spectroscopy. Applied Spectroscopy. 2001;55(9):1259-1265.

33. Agostini D. Characterization of latex and natural rubber constituints that angiogenesis stimulates. [Master Dissertation], Presidente Prudente, Brazil: São Paulo State University (UNESP). 2009;87.

34. Job AE, Constantino CJL, Mendes TSG, Teruya MY, Alves N, Mattoso LHC. Effect of natural rubber latex on the conducting state of polyaniline blends determined by Raman spectroscopy. Journal of Raman Spectroscopy. 2003;34:831-836.

35. Lee ASL, Li YL. Surface-enhanced Raman, normal Raman and infrared spectra of chlorobenzoic acids. Spectrochimica Acta Part A: Molecular and Biomolecular Spectroscopy. 1996;52(2): 173-184.

36. Sideroudi T, Pharmakakis N, Tyrovolas A, Papatheodorou G, Chryssikos GD, Voyiatzis GA. Non-contact detection of ciprofloxacin in a model anterior chamber using Raman spectroscopy. Journal of Biomedical Optics. 2007;12.
37. Simoes RD, Job AE, Chinaglia DL, Zucolotto V, Camargo-Filho JC, Alves N, Giacometti JA, Oliveira ON, Constantino CJL. Structural characterization of blends containing both PVDF and natural rubber latex. Journal of Raman Spectroscopy. 2005;36:1118-1124.

38. Dall'Antonia AC, Martins MA, Moreno RMB, Mattoso LHC, Gonçalves PS, Job AE. Mechanical and thermal characterization of compounds of natural rubber of the clones: GT 1, IAN 873, PB 235 and RRIM 600. Polímeros. 2009;19:63-71.

39. Unnithan AR, Barakat NAM, Pichiah PBT, Gnanasekaran G, Nirmala R, Cha YS, et al. Wound-dressing materials with antibacterial activity from electrospun polyurethane-dextran nano-fiber mats containing ciprofloxacin $\mathrm{HCl}$. Carbohydrate Polymers. 2012;90:1786-93.

40. Macocinschi D, Filip D, Vlad S, Tuchilus CG, Cristian AF, Barboiu M. Polyurethane/ $\beta$-cyclodextrin/ciprofloxacin composite films for possible medical coatings with antibacterial properties. Journal of Material Chemistry B. 2014;2:681-90.

41. Herculano RD. Development of natural rubber membranes to medical applications. [PhD Thesis]. Riberão Preto, Brazil: São Paulo University (USP). 2009;150.

Available:http://www.teses.usp.br/teses/dis poniveis/59/59135/tde-05082009141412/pt-br.php

(C) 2017 Garms et al.; This is an Open Access article distributed under the terms of the Creative Commons Attribution License (http://creativecommons.org/licenses/by/4.0), which permits unrestricted use, distribution, and reproduction in any medium, provided the original work is properly cited.

\section{Peer-review history:}

The peer review history for this paper can be accessed here: http://sciencedomain.org/review-history/18126 